\title{
HUBUNGAN TEKSTUR SEDIMEN DENGAN KERAPATAN MANGROVE DI KAWASAN KONSERVASI MANGROVE DI DESA PASAR BANGGI, REMBANG
}

\author{
Correlation between Sediment Texture and Mangrove Density \\ at Pasar Banggi Village, Rembang \\ Arfin Rizal Aprinantyo, Supriharyono*), Haeruddin \\ Program Studi Manajemen Sumberdaya Perairan \\ Departemen Sumberdaya Akuatik Fakultas Perikanan dan Ilmu Kelautan, Universitas Diponegoro \\ Jl. Prof. Soedharto, SH, Tembalang, Semarang, Jawa Tengah-50275 \\ Emil : arfinrizal44@gmail.com
}

\begin{abstract}
ABSTRAK
Pasar Banggi merupakan salah satu desa pesisir yang berjarak sekitar $11 \mathrm{~km}$ dari kota Rembang. Kawasan mangrove di Desa Pasar Banggi Rembang merupakan kawasan mangrove yang dijadikan tempat konservasi sekaligus sebagai tempat wisata. Mangrove Rhizophora sp. jangkauan akarnya dapat meredam gelombang laut, oleh karena itu spesies ini tumbuh pada bagian terluar pantai. Tujuan dari penelitian ini adalah untuk mengetahui tipe tekstur sedimen, kerapatan mangrove serta hubungan tekstur sedimen dengan kerapatan mangrove di Desa Pasar Banggi, Rembang. Penelitian ini dilaksanakan pada bulan Agustus 2017. Metode penelitian yang digunakan adalah metode kuantitatif yang bersifat deskriptif dengan menggunakan teknik purposive sampling. Lokasi sampling dibagi menjadi 3 stasiun pengamatan, tiap stasiun dibagi menjadi 3 titik pengambilan sampel. Hasil yang diperoleh dari tekstur sedimen mangrove di Desa Pasar Banggi, Rembang didominasi oleh lumpur dengan nilai antara (90,74-100\%), sedangkan liat berkisar antara (0-7,02\%), dan pasir memiliki nilai berkisar antara (0-3,85\%). Kerapatan mangrove di Desa Pasar Banggi didominasi oleh jenis mangrove Rhizophora sp.. Nilai kerapatan relatif Rhizophora sp. di stasiun 1, 2 dan 3 yaitu berkisar dari (837-25.400 pohon/ha). Hasil uji regresi linier berganda menunjukkan bahwa hubungan tekstur sedimen dengan kerapatan mangrove di stasiun 1 (kerapatan jarang) mempunyai hubungan yang sangat kuat dengan angka koefisien korelasi (R) sebesar 0,741, stasiun 2 (kerapatan sedang) mempunyai hubungan yang sangat lemah dengan angka koefisien korelasi (R) sebesar 0,388, dan stasiun 3 (kerapatan rapat) mempunyai hubungan sedang dengan angka koefisien korelasi (R) sebesar 0,473 .
\end{abstract}

Kata Kunci: Tekstur Sedimen; Kerapatan Mangrove; Kawasan Konservasi; Pasar Banggi Rembang

\section{ABSTRACT}

Pasar Banggi is one of villages, that located on coastal area wich is $11 \mathrm{~km}$ from Rembang City. Mangrove area in Pasar Banggi Village is used both as conservation and a tourist destination. Rhizophora sp. Root can reduce the ocean wave, so that it grew on the outline of coastal zone. The purpose of this research are to identify the type of sediment texture, mangrove density and to examine the correlation between sediment texture and mangrove density at Pasar Banggi Village, Rembang. This study had been carried out from August 2017. Research method used in this research is descriptive quantitative method using purposive sampling technique. Sampling area is divided into 3 stations, each station is divided into 3 sampling points. The results showed that sediment texture in Pasar Banggi Village, Rembang are dominated by silt (90.74-100\%), while clay ranged from (0-7.02\%), and sand has a value ranging from (0-3.85\%). Mangrove density in Pasar Banggi Village is dominated by Rhizophora sp. The relative density value of Rhizophora sp. at stations 1, 2 and 3 ranging from (837-25,400 trees/ha). The results of multiple linear regression test showed that sediment texture with mangrove density at station 1 (rare density) has a very strong relationship with the correlation coefficient $(R)$ of 0,741 station 2 (medium density) has very weak relationship with the coefficient of correlation $(R)$ is 0,388 , and station 3 (dense) has medium relationship with the coefficient of correlation $(R)$ of 0,473 .

Keywords: Sediment Texture; Mangrove Density; Conservation Area; Pasar Banggi Rembang

*) Penulis penanggungjawab 


\section{PENDAHULUAN}

Pasar Banggi merupakan salah satu desa pesisir yang berjarak sekitar $11 \mathrm{~km}$ dari kota Rembang. Laut Jawa merupakan batas sebelah utara dari desa ini, sedangkan sebelah selatan, timur, maupun barat berbatasan dengan desa lain yang masih dalam lingkup Kecamatan Rembang. Bila dibandingkan dengan dua desa lainnya, Pasar Banggi merupakan desa yang memiliki wilayah terluas (410.905 ha), garis pantai terpanjang $(2,7 \mathrm{~km})$ dan jumlah penduduk terbanyak (2949 orang). Komposisi penduduk terdiri atas 1485 laki-laki dan 1464 perempuan. Meskipun sebagian besar warganya bermata pencaharian pokok sebagai nelayan (71 \%), namun banyak juga yang berprofesi sebagai petani maupun buruh tani $(11 \%)$ mengingat hampir 275 ha dari luas desa ini merupakan areal persawahan. Terdapat tiga sungai yang bermuara langsung ke Laut Jawa, yaitu Sungai Sepeking, Sungai Pasar Banggi, dan Sungai Ploso. Desa ini memiliki 1 dukuh yaitu Dukuh Kaliuntu (Auliyani et al., 2014).

Ekosistem mangrove di Kabupaten Rembang dapat ditemui salah satunya di Desa Pasar Banggi, Kecamatan Rembang. Kondisi ekosistem mangrove disana tergolong salah satu yang terbaik di Pantura Jawa Tengah. Usaha pengelolaan ekosistem mangrove di Desa Pasar Banggi dimulai sejak tahun 1960 dengan melakukan rehabilitasi terutama secara swadaya oleh masyarakat. Pengelolaan dan perlindungan disana dinilai cukup berhasil terbukti dengan kondisi ekosistem mangrove yang masih relatif baik dan juga kesadaran masyarakat akan pentingnya ekosistem mangrove di Desa Pasar Banggi, Kabupaten Rembang sudah cukup tinggi. Kondisi tersebut diatas, dianggap merupakan suatu kondisi yang cukup positif dan bisa dijadikan contoh yang baik untuk diterapkan di daerah yang lain. (Annas, 2013)

Pada umumnya pohon mangrove mempunyai satu atau lebih tipe akar. Berbagai bentuk perakaran tersebut merupakan salah satu cara adaptasi tumbuhan mangrove terhadap kondisi habitat yang sering tergenang air pasang. Sebagai contoh, bakau mempunyai sejumlah bentuk khusus yang memungkinkan mereka untuk hidup di perairan lautan yang dangkal yaitu berakar pendek, menyebar luas dengan akar penyangga atau tudung akarnya yang khas tumbuh dari batang dan atau dahan. Akar-akar yang dangkal sering memanjang disebut pneumatofor ke permukaan substrat yang memungkinkan tumbuhan bakau mendapat oksigen dalam lumpur (Karuniastuti, 2010).

Tekstur sedimen dipisahkan berdasarkan ukuran butiran sedimennya. Pengukuran tekstur sedimen memisahkan ukuran sedimen menjadi lumpur, liat, dan pasir. Perubahan lingkungan di alam akan sangat berpengaruh pada kondisi fisika, kimia, dan biologi sedimen yang ada. Namun yang sangat berpengaruh pada kondisi fisik sedimen yaitu adanya proses pengadukan maupun pengendapan yang sangat dipengaruhi oleh kondisi lingkungan seperti arus. Arus akan mempengaruhi proses laju pengendapan atau sedimentasi dan mempengaruhi ukuran butir sedimen yang terendapkan (Kinasih et al., 2015).

Keadaan pesisir Pasar Banggi, Rembang yang didominasi oleh pantai bermangrove telah mengalami banyak rehabilitasi. Namun tidak semua usaha masyarakat untuk memperkokoh sabuk laut tersebut berhasil. Kondisi sedimen yang rapuh apabila terkena gelombang dan arus setiap harinya terkadang membuat usaha masyarakat tersebut sia-sia. Kondisi yang sekarang terjadi menunjukkan bahwa wilayah pesisir Pasar Banggi luasnya makin berkurang. Usaha yang dilakukan untuk memperoleh informasi mengenai kondisi sedimen dan mangrove yaitu dengan melakukan penelitian tentang kerapatan mangrove, tekstur sedimen, dan salinitas sedimen.

Tujuan dari penelitian ini adalah :

1. Mengetahui tipe tekstur sedimen mangrove di Desa Pasar Banggi, Rembang

2. Mengetahui kerapatan mangrove di kawasan mangrove Desa Pasar Banggi, Rembang

3. Mengetahui hubungan truktur sedimen dengan kerapatan mangrove Desa Pasar Banggi, Rembang

\section{MATERI DAN METODE PENELITIAN}

Pengambilan sampel dilakukan pada 3 stasiun pengamatan, tiap stasiun dibagi menjadi 3 titik pengambilan sampel. Penentuan stasiun dilihat berdasarkan vegetasi mangrove dengan 3 tegakan yang berbeda yaitu rapat, sedang dan jarang. Menurut Keputusan Menteri Negara Lingkungan Hidup No. 201 tahun 2004 dalam Susiana (2011), Kriteria Baku Kerapatan Mangrove yaitu dikatakan padat apabila kerapatannya $\geq 1.500$ pohon/ha. Kemudian akan dikatakan sedang apabila kerapatannya $\geq 1.000-1.500$ pohon/ha, dan akan dikatakan jarang apabla kerapatannya $\leq 1.000$ pohon/ha. Pada masing-masing stasiun dilakukan pengamatan tekstur sedimen, salinitas dan kerapatan ekosistem mangrove. Pengamatan kerapatan mangrove dengan menggunakan metode Point Quarter Method. Metode ini dilakukan pengukuran jarak antar individu tumbuhan atau jarak dari pohon yang dipilih secara acak terhadap individu-individu tumbuhan yang terdekat. Pada titik pengambilan sampel akan dibuat dua buah garis maya yang menjadikan titik tersebut sebagai pusat sehingga akan didapatkan empat buat kuadran. Pada tiap kuadran akan dipilih satu pohon yang terdekat dari titik pusat, kemudian akan diukur jaraknya. Pada keempat pohon terdekat itu juga akan dilakukan pencatatan jenis dan keliling batang pohon dan dilakukan pengamatan tekstur sedimen dan salinitas sedimen. Gambaran kuadran dan pengukuran jarak pohon pada metode Point Centered Quarter tersaji dalam Gambar 1. 


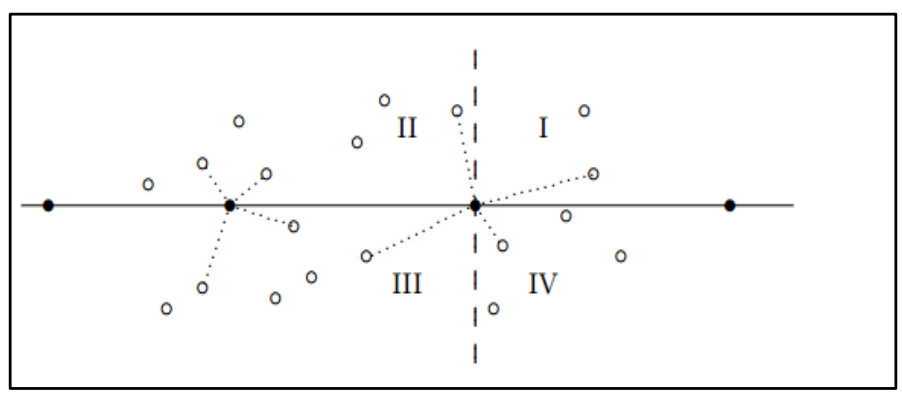

Gambar 1. Skema Metode Point Centered Quarter

Pengukuran vegetasi mangrove dilakukan dengan metode titik pusat kuadran (Point Quarter Method). Metode ini juga digunakan oleh Susiana (2011), apabila menggunakan Metode Point Centered Quarter akan mempermudah menghitung jumlah semua tegakan mangrove. Mangrove yang diukur adalah mangrove yang berada di Point Centered Quarter, dimana dipilih pohon yang paling dekat di setiap kuarter. Menurut Mitchell (2007), untuk menghitung kerapatan relatif suatu ekosistem hutan mangrove, maka akan menggunakan rumusrumus sebagai berikut :

1. Menghitung jarak rata-rata antar pohon, dengan rumus :

Jarak rata-rata tiap pohon $(\hat{\mathrm{r}})=\frac{\sum \text { Jarak Pohon }}{\sum \text { Jumlah Pohon }}$

2. Menghitung kerapatan absolut total, dengan rumus :

Kerapatan Absolut Total $(\boldsymbol{\lambda})=\frac{1}{\mathrm{r}^{\wedge} 2}$

Kerapatan Absolut tiap spesies $=\frac{\text { Frekuensi Kemunculan Spesies }}{\text { Total kuadran }}$

3. Menghitung kerapatan relatif tiap spesies, dengan rumus :

Kerapatan Absolut tiap spesies $=\frac{\text { Jumlah Pohon }}{\text { Total Jumlah Pohon }} \times 100 \%$

Pengukuran tekstur sedimen dilakukan dengan menggunakan metode Soil Jar Test (FAO, 2016) yaitu dengan menggunakan gelas ukur berukuran $500 \mathrm{ml}$ yang diisi sekitar setengah penuh dengan sedimen. Gelas ukur yang telah berisi sedimen diisi hampir penuh dengan air. Tutup gelas ukur dengan penutup plastik dan gelas ukur dikocok selama beberapa menit sehingga semua partikel tercampur. Diamkan selama 2 jam sehingga partikel dapat menetap. Partikel pasir yang lebih berat akan mengendap di bagian bawah, kemudian lumpur, kemudian liat di atas. Ketinggian semua 3 lapisan sedimen diukur dari setiap lapisan. Ketinggian setiap lapisan dibagi dengan tinggi total untuk mengetahui persentase masing-masing tanah dan dapat dianalisa jenis tekstur sedimennya dengan menggunakan Segitiga Sheppard. Selanjutnya hasil yang didapat dari metode Soil Jar Test akan dianalisa menggunakan Segitiga Sheppard. Menurut Munandar et al., (2014), analisis karakteristik sedimen dengan menggunakan Segitiga Sheppard merupakan perhitungan yang didasarkan pada proporsi kandungan ukuran partikel kerikil, pasir, dan lumpur. Sistem klasifikasi ini berdasarkan Median diameter (Md). Sistem dari tiga komponen yang berjumlah 100\%. Diagram Sheppard mengikuti konversi semua diagram rangkap tiga. Sebagai contoh, lumpur berisi sedikitnya 75\% partikel-partikel ukuran lumpur. "Silt Sand" dan "Sandy Silt" berisi tidak lebih dari pada 20\% ukuran partikel "Clay" dan "Sand-Silt Clays" berisi sedikitnya 20\% dari setiap ketiga komponen-komponen. Contoh segitiga tekstur sedimen tersaji dalam Gambar 2.

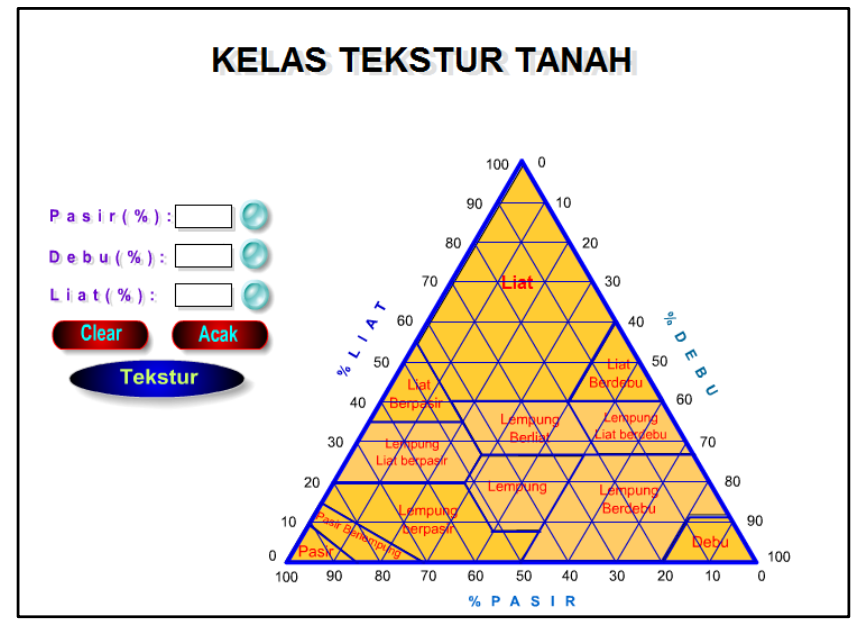

Gambar 2. Segitiga Sheppard 
Analisa data yang digunakan dalam penelitian ini adalah Analisis Komponen Utama (Principal Component Analysis) dan regresi linear berganda. Analisa PCA ini digunakan untuk mengubah bentuk sejumlah variabel berkorelasi menjadi beberapa variabel yang berdiri sendiri atau tidak berkorelasi tanpa mengurangi atau menghilangkan informasi yang ada didalamnya. Variabel bebas yaitu clay, silt, sand, dan salinitas, sedangkan untuk variabel tidak bebas yaitu kerapatan mangrove. Menurut Jolliffe (2002), tujuan dari analisa PCA adalah untuk mereduksi variabel yang ada menjadi lebih sedikit tanpa harus kehilangan informasi yang termuat dalam data asli/awal.

Analisis untuk menentukan hubungan tekstur sedimen (clay, silt dan sand), salinitas dengan kerapatan mangrove menggunakan uji regresi linear berganda. Uji regresi linear berganda dilakukan untuk mengetahui keeratan hubungan dan pengaruh variabel bebas (independen) $\mathrm{X}_{1}, \mathrm{X}_{2}, \mathrm{X}_{3}, \mathrm{X}_{4}$ terhadap variabel tak bebas (dependen) Y.

Keterangan:

$$
Y=a+b X_{1}+b X_{2}+b X_{3}+b X_{4}
$$

$$
\begin{array}{ll}
\mathrm{a} & =\text { Konstanta } \\
\mathrm{b} & =\text { Koefisien regresi (nilai peningkatan ataupun penurunan) } \\
\mathrm{Y} & =\text { Kerapatan mangrove } \\
\mathrm{X}_{1} & =\text { Clay } \\
\mathrm{X}_{2} & =\text { Silt } \\
\mathrm{X}_{3} & =\text { Sand } \\
\mathrm{X}_{4} & =\text { Salinitas }
\end{array}
$$

Pencegahan terhadap kemungkinan terjadinya masalah kolinearitas dalam regresi dilakukan agar model regresi yang diperoleh memiliki akurasi yang tinggi.

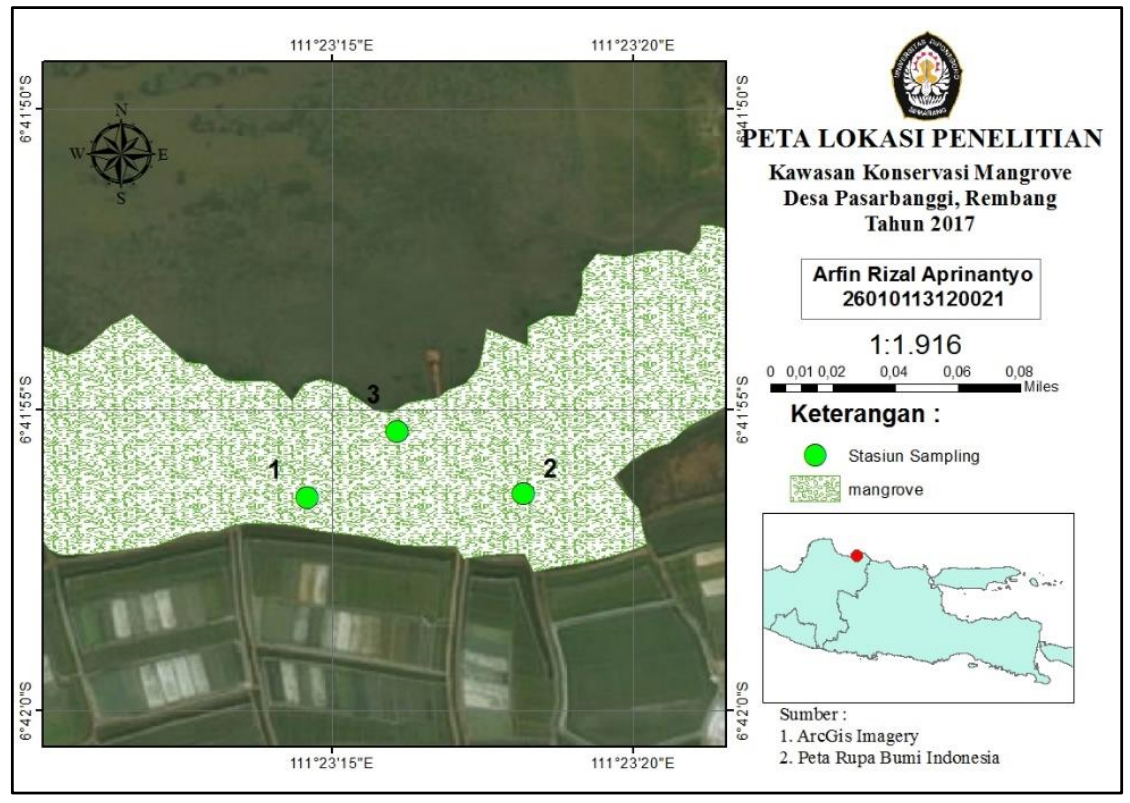

Gambar 3. Peta Lokasi Penelitian

\section{HASIL DAN PEMBAHASAN}

Kerapatan Mangrove

Hasil pengukuran kerapatan mangrove tersaji pada Tabel 1.

Tabel 1. Hasil Kerapatan Mangrove di Desa Bedono

\begin{tabular}{cccccc}
\hline Stasiun & Titik & $\begin{array}{c}\text { Kerapatan } \\
\text { (pohon/Ha) }\end{array}$ & $\begin{array}{c}\text { Diameter } \\
(\mathbf{c m})\end{array}$ & Kriteria Baku $*$ & $\begin{array}{c}\text { Komposisi Jenis } \\
\text { Mangove }\end{array}$ \\
\hline \multirow{2}{*}{ I } & 1 & 750 & $9,87-11,78$ & $<1000$ (jarang) & $\begin{array}{l}\text { Rhizopora } \text { sp. } \\
\text { Rhizopora } \text { sp. }\end{array}$ \\
& 2 & 860 & $11,15-13,38$ & $<1000$ (jarang) & Rhizopora sp. \\
\hline \multirow{2}{*}{ II } & 3 & 920 & $10,51-11,78$ & $<1000$ (jarang) & Rhizopora sp. \\
& 1 & 1040 & $5,73-15,29$ & $>1000-<1500$ (sedang) & Rhizopora sp. \\
& 2 & 1470 & $9,87-13,38$ & $>1000-<1500$ (sedang) & Rhizopora sp. \\
\hline \multirow{2}{*}{ III } & 3 & 1370 & $7,64-14,97$ & $>1000-<1500$ (sedang) & Rhizopora sp. \\
& 1 & 1960 & $6,37-9,55$ & $>1500$ (rapat) & Rhizopora sp.
\end{tabular}

${ }^{\odot}$ Copyright by Management of Aquatic Resources (MAQUARES) 
$\begin{array}{ccc}3 & 5880 & 6,37-8,28\end{array}$

Kerapatan mangrove paling tinggi berada pada stasiun tiga yaitu sebanyak 1960-5880 pohon/Ha, kerapatan mangrove sedang pada stasiun dua yaitu sebanyak 1040-1470 pohon/Ha, dan kerapatan mangrove jarang pada stasiun satu yaitu sebanyak 750-920 pohon/Ha.

Tekstur Sedimen

Hasil pengukuran tekstur sedimen dapat dilihat pada Tabel 2.

Tabel 2. Hasil Pengukuran Tekstur Sedimen Stasiun 1 (Kerapatan Jarang)

\begin{tabular}{cccccc}
\hline \multirow{2}{*}{ Titik } & \multirow{2}{*}{ Pengulangan } & \multicolumn{3}{c}{ Persentase Tekstur Sedimen } & \multirow{2}{*}{ Tekstur } \\
\cline { 2 - 4 } & & Clay & Silt & Sand & Sedimen \\
\hline 1 & 1 & 3,92 & 96,08 & 0,00 & Lumpur \\
& 2 & 5,08 & 91,53 & 3,39 & Lumpur \\
& 3 & 7,02 & 91,23 & 1,75 & Lumpur \\
& 4 & 7,02 & 91,23 & 1,75 & Lumpur \\
\hline
\end{tabular}

Tabel 3. Hasil Pengukuran Tekstur Sedimen Stasiun 1 (Kerapatan Jarang)

\begin{tabular}{ccccrc}
\hline \multirow{2}{*}{ Titik } & \multirow{2}{*}{ Pengulangan } & \multicolumn{3}{c}{ Persentase Tekstur Sedimen } & \multirow{2}{*}{ Tekstur } \\
\cline { 2 - 4 } & & Clay & Silt & Sand & Sedimen \\
\hline 2 & 1 & 1,85 & 96,30 & 1,85 & Lumpur \\
& 2 & 1,92 & 96,15 & 1,92 & Lumpur \\
& 3 & 0,00 & 98,00 & 2,00 & Lumpur \\
& 4 & 3,70 & 92,59 & 3,70 & Lumpur \\
\hline
\end{tabular}

Tabel 4. Hasil Pengukuran Tekstur Sedimen Stasiun 1 (Kerapatan Jarang)

\begin{tabular}{cccccc}
\hline \multirow{2}{*}{ Titik } & Pengulangan & \multicolumn{3}{c}{ Persentase Tekstur Sedimen } & \multirow{2}{*}{ Tekstur } \\
\cline { 2 - 4 } & & Clay & Silt & Sand & \\
\cline { 2 - 5 } & 1 & 2,04 & 95,92 & 2,04 & Lumpur \\
\hline 3 & 2 & 3,70 & 92,59 & 3,70 & Lumpur \\
& 3 & 5,56 & 90,74 & 3,70 & Lumpur \\
& 4 & 4,08 & 93,88 & 2,04 & Lumpur \\
\hline
\end{tabular}

Tabel 5. Hasil Pengukuran Tekstur Stasiun 2 (Kerapatan Sedang)

\begin{tabular}{cccccc}
\hline \multirow{2}{*}{ Titik } & \multirow{2}{*}{ Pengulangan } & \multicolumn{3}{c}{ Persentase Tekstur Sedimen } & \multirow{2}{*}{ Tekstur } \\
\cline { 2 - 4 } & & Clay & Silt & Sand & \\
\cline { 2 - 5 } & 1 & 3,92 & 94,12 & 1,96 & Lumpur \\
\hline 1 & 3,92 & 94,12 & 1,96 & Lumpur \\
& 3 & 0,00 & 96,23 & 3,77 & Lumpur \\
& 4 & 1,96 & 98,04 & 0,00 & Lumpur \\
\hline
\end{tabular}

Tabel 6. Hasil Pengukuran Tekstur Stasiun 2 (Kerapatan Sedang)

\begin{tabular}{ccrrrr}
\hline \multirow{2}{*}{ Titik } & \multirow{2}{*}{ Pengulangan } & \multicolumn{3}{c}{ Persentase Tekstur Sedimen } & \multirow{2}{*}{ Tekstur } \\
\cline { 2 - 4 } & & Clay & \multicolumn{1}{c}{ Silt } & Sand & Sedimen \\
\hline 2 & 1 & 1,79 & 94,64 & 3,57 & Lumpur \\
& 2 & 0,00 & 100,00 & 0,00 & Lumpur \\
& 3 & 3,64 & 92,73 & 3,64 & Lumpur \\
& 4 & 0,00 & 98,04 & 1,96 & Lumpur \\
\hline
\end{tabular}

Tabel 7. Hasil Pengukuran Tekstur Stasiun 2 (Kerapatan Sedang)

\begin{tabular}{lccc}
\multirow{2}{*}{ Titik } & Pengulangan & $\begin{array}{c}\text { Persentase Tekstur Sedimen } \\
(\%)\end{array}$ & $\begin{array}{c}\text { Tekstur } \\
\text { Sedimen }\end{array}$ \\
\hline
\end{tabular}

${ }^{\circledR}$ Copyright by Management of Aquatic Resources (MAQUARES) 


\begin{tabular}{cccccc}
\hline & & Clay & Silt & Sand & \\
\hline 3 & 1 & 2,04 & 97,96 & 0,00 & Lumpur \\
& 2 & 1,82 & 94,55 & 3,64 & Lumpur \\
& 3 & 2,00 & 98,00 & 0,00 & Lumpur \\
& 4 & 0,00 & 100,00 & 0,00 & Lumpur \\
\hline
\end{tabular}

Tabel 8. Hasil Pengukuran Tekstur Stasiun 3 (Kerapatan Rapat)

\begin{tabular}{cccrrr}
\hline \multirow{2}{*}{ Titik } & Pengulangan & \multicolumn{3}{c}{ Persentase Tekstur Sedimen } & \multirow{2}{*}{ Tekstur } \\
\cline { 2 - 4 } & & Clay & \multicolumn{1}{c}{ Silt } & Sand & Sedimen \\
\hline 1 & 1,96 & 96,08 & 1,96 & Lumpur \\
& 2 & 0,00 & 100,00 & 0,00 & Lumpur \\
& 3 & 5,36 & 91,07 & 3,57 & Lumpur \\
& 4 & 1,96 & 98,04 & 0,00 & Lumpur \\
\hline
\end{tabular}

Tabel 9. Hasil Pengukuran Tekstur Stasiun 3 (Kerapatan Rapat)

\begin{tabular}{cccccc}
\hline \multirow{2}{*}{ Titik } & Pengulangan & \multicolumn{3}{c}{ Persentase Tekstur Sedimen } & \multirow{2}{*}{ Tekstur } \\
\cline { 2 - 4 } & & Clay & Silt & Sand & \\
\hline 2 & 1 & 3,77 & 94,34 & 1,89 & Lumpur \\
\hline 2 & 2,04 & 97,96 & 0,00 & Lumpur \\
& 3 & 3,64 & 94,55 & 1,82 & Lumpur \\
& 4 & 3,70 & 94,44 & 1,85 & Lumpur \\
\hline
\end{tabular}

Tabel 10. Hasil Pengukuran Tekstur Stasiun 3 (Kerapatan Rapat)

\begin{tabular}{|c|c|c|c|c|c|}
\hline \multirow[t]{2}{*}{ Titik } & \multirow[t]{2}{*}{ Pengulangan } & \multicolumn{3}{|c|}{$\begin{array}{c}\text { Persentase Tekstur Sedimen } \\
(\%)\end{array}$} & \multirow{2}{*}{$\begin{array}{l}\text { Tekstur } \\
\text { Sedimen }\end{array}$} \\
\hline & & Clay & Silt & Sand & \\
\hline \multirow[t]{4}{*}{3} & 1 & 1,92 & 94,23 & 3,85 & Lumpur \\
\hline & 2 & 5,17 & 91,38 & 3,45 & Lumpur \\
\hline & 3 & 3,70 & 94,44 & 1,85 & Lumpur \\
\hline & 4 & 2,00 & 96,00 & 2,00 & Lumpur \\
\hline
\end{tabular}

Berdasarkan hasil penelitian yang telah dilakukan dapat dilihat bahwa tekstur sedimen pada lokasi penelitian memiliki komposisi yang tidak terlalu berbeda. Didapatkan jenis lumpur, liat dan pasir. Stasiun 1, 2 dan 3 banyak ditemukan jenis tekstur lumpur (silt). Pada lokasi penelitian jenis tekstur liat (clay) dan pasir (sand) tidak terlalu banyak ditemukan.

\section{Salinitas Sedimen}

Hasil pengukuran salinitas sedimen tersaji pada Tabel 11.

Tabel 11. Hasil Rata-Rata Pengukuran Salinitas Sedimen

\begin{tabular}{ccc}
\hline Stasiun & Titik & Salinitas (\%o) \\
\hline S.I & 1 & 30 \\
Kerapatan & 2 & 29 \\
jarang & 3 & 30 \\
\hline S.II & 1 & 30 \\
Kerapatan & 2 & 29 \\
sedang & 3 & 31 \\
\hline S.III & 1 & 31 \\
Kerapatan & 2 & 30 \\
rapat & 3 & 31 \\
\hline
\end{tabular}

Berdasarkan hasil pengukuran salinitas sedimen yang telah dilakukan nilai salinitas stasiun 1 berkisar antara 29-30 ppt, stasiun 2 berkisar 29-31 ppt, dan stasiun 3 berkisar antara 30-31.

Analisa PCA (Principal Component Analysis)

Hasil PCA (Principal Component Analysis)

${ }^{\circledR}$ Copyright by Management of Aquatic Resources (MAQUARES) 


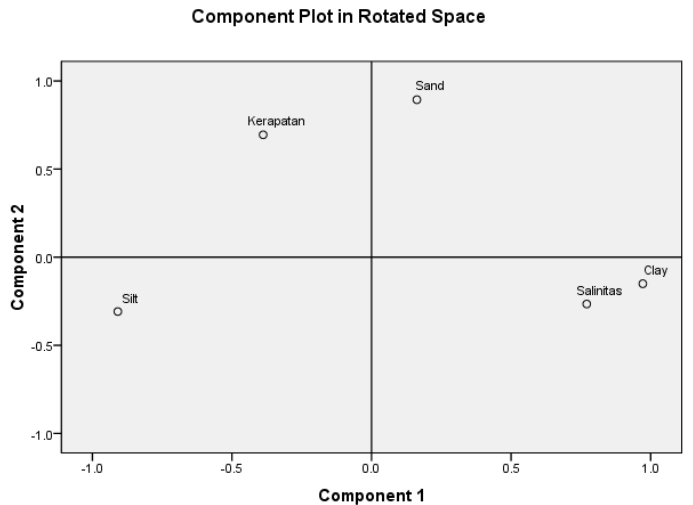

Gambar 4. Peta Analisa PCA terhadap tekstur sedimen dengan kerapatan mangrove jarang di kawasan konservasi mangrove di Desa Pasar Banggi, Rembang

Berdasarkan peta di atas, component 1 memiliki kontribusi sebesar 51,53\% dan component 2 memiliki kontribusi sebesar $28,71 \%$. Berdasarkan peta tersebut dapat diketahui bahwa ada keterkaitan antara lumpur (silt) dengan kerapatan mangrove, adapun pasir (sand), liat (clay) dan salinitas juga memiliki hubungan keterkaitan. Hal tersebut menunjukkan apabila semakin banyak lumpur (silt) yang ada dalam komposisi tekstur sedimen, maka mangrove yang banyak tumbuh adalah jenis Rhizophora sp.

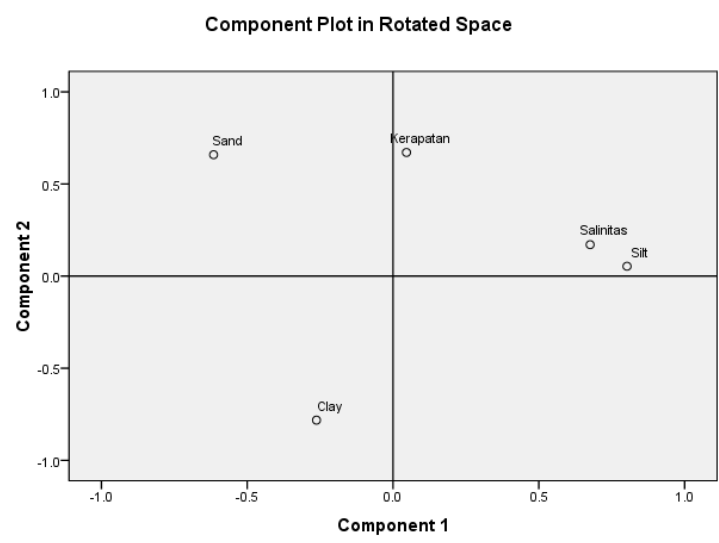

Gambar 5. Peta Analisa PCA terhadap tekstur sedimen dengan kerapatan mangrove sedang di kawasan konservasi mangrove di Desa Pasar Banggi, Rembang

Berdasarkan peta di atas, component 1 memiliki kontribusi sebesar 31,09\% dan component 2 memiliki kontribusi sebesar 30,47\%. Berdasarkan peta tersebut dapat diketahui bahwa ada keterkaitan antara lumpur (silt) dan salinitas dengan kerapatan mangrove, adapun liat (clay) dan pasir (sand) juga memiliki hubungan keterkaitan. Hal tersebut menunjukkan apabila semakin banyak lumpur (silt) dan salinitas yang ada dalam komposisi tekstur sedimen, maka mangrove akan banyak tumbuh dan mangrove yang tumbuh adalah jenis Rhizophora sp. 


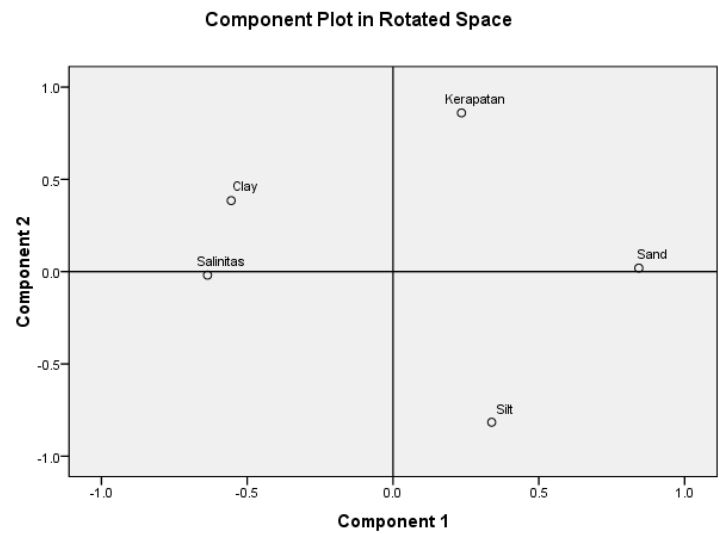

Gambar 6. Peta Analisa PCA terhadap tekstur sedimen dengan kerapatan mangrove rapat di kawasan konservasi mangrove di Desa Pasar Banggi, Rembang

Berdasarkan peta di atas, component 1 memiliki kontribusi sebesar 36,68\% dan component 2 memiliki kontribusi sebesar 26,27\%. Berdasarkan peta tersebut dapat diketahui bahwa ada keterkaitan antara lumpur (silt) dan pasir (sand) dengan kerapatan mangrove, adapun liat (clay) dan salinitas juga memiliki hubungan keterkaitan. Hal tersebut menunjukkan apabila semakin banyak lumpur (silt) yang ada dalam komposisi tekstur sedimen, maka mangrove yang banyak tumbuh adalah jenis Rhizophora sp.. Kemudian parameter liat (clay) berkorelasi dengan salinitas.

\section{Analisa Regresi Linear}

Hasil Analisa Regresi Linear

Tabel 12. Persamaan Regresi Linear Ganda Stasiun 1 Kerapatan Jarang

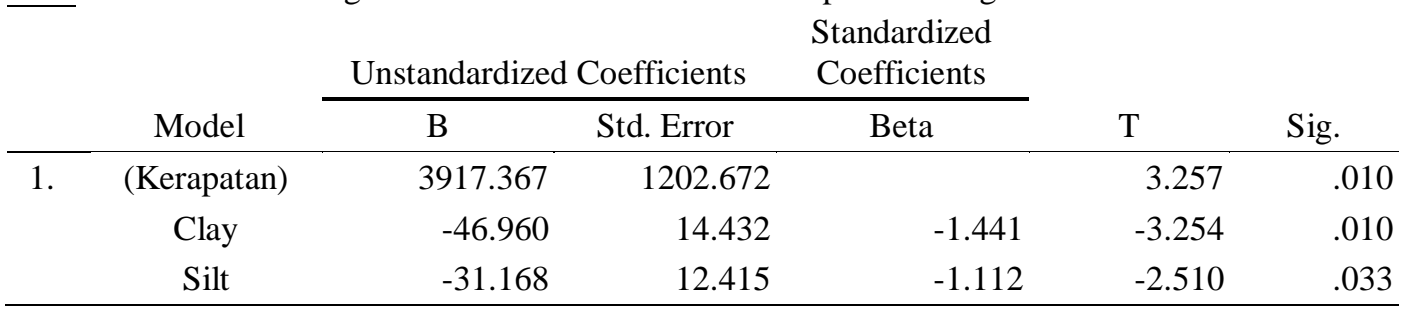

a. Dependent Variable: Kerapatan

Berdasarkan Tabel 12 model regresi linear berganda Stasiun 1 (Kerapatan Jarang) diperoleh persamaan yaitu $\mathrm{Y}=3917.367-46.960 \mathrm{X}_{1}-31.168 \mathrm{X}_{2}$. Hasil analisis pada tabel menunjukkan clay nilai t hitung sebesar 3,254 dengan probabilitas $=0,010<0,05$ artinya clay berpengaruh signifikan, silt nilai t hitung sebesar $-2,510$ dengan probabilitas $=0,033<0,05$ artinya silt memiliki pengaruh yang signifikan, terhadap kerapatan mangrove jarang

Tabel 13. Kesimpulan Model Analisis Regresi Berganda Stasiun 1 Kerapatan Jarang

\begin{tabular}{lllll}
\hline Model & $\mathrm{R}$ & $\mathrm{R}^{2}$ & Adjusted $\mathrm{R}^{2}$ & Std. Error of the Estimate \\
\hline 1 & $0,741^{\mathrm{a}}$ & 0,548 & 0,448 & 55,05619 \\
\hline
\end{tabular}

Berdasarkan Tabel 13 diperoleh nilai koefisien korelasi (R) sebesar 0,741 yang berarti hubungan clay dan silt dengan kerapatan mangrove dikategorikan berhubungan kuat. Nilai koefisien determinasi $\left(\mathrm{R}^{2}\right)$ sebesar 0,548 nilai ini menunjukkan sebesar 54,8\% kerapatan mangrove jarang dipengaruhi oleh clay dan silt, sisanya sebesar $94,6 \%$ dipengaruhi oleh faktor lain seperti faktor fisika kimia yang ada pada perairan.

Tabel 14. Persamaan Regresi Linear Ganda Stasiun 2 Kerapatan Sedang

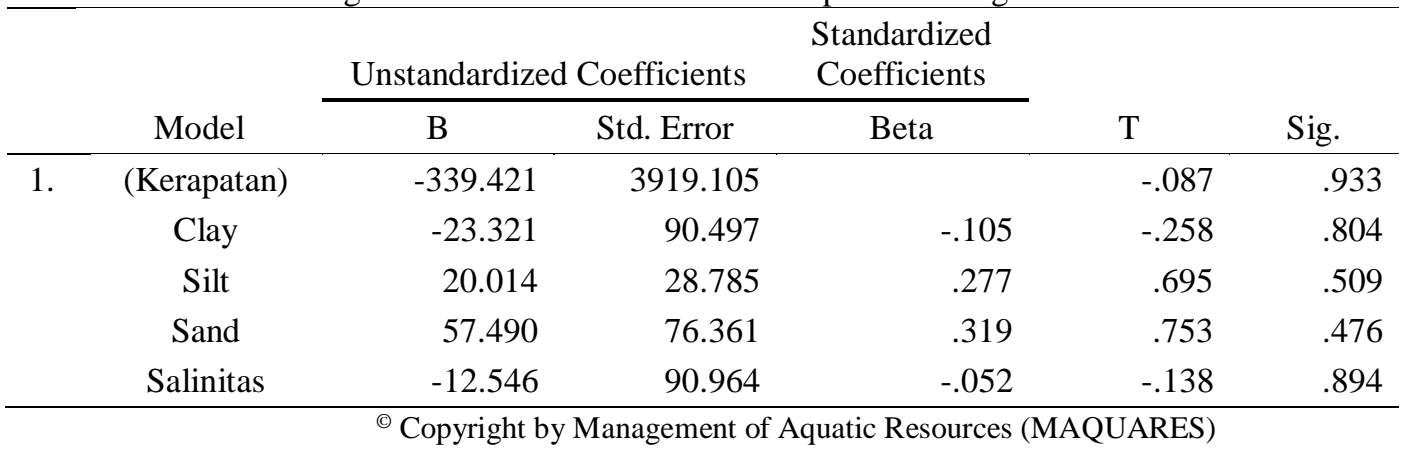


a. Dependent Variable: Kerapatan

Berdasarkan Tabel 14 model regresi linear berganda Stasiun 2 (Kerapatan Sedang) diperoleh persamaan yaitu $\mathrm{Y}=-339.421-23.321 \mathrm{X}_{1}+20.014 \mathrm{X}_{2}+57.490 \mathrm{X}_{3}-12.546 \mathrm{X}_{4}$. Hasil analisis pada tabel menunjukkan clay nilai t hitung sebesar $-0,258$ dengan probabilitas $=0,804>0,05$ artinya clay tidak berpengaruh signifikan, silt nilai t hitung sebesar 0,695 dengan probabilitas $=0,509>0,05$ artinya silt tidak memiliki pengaruh yang signifikan, sand nilai t hitung sebesar 0,753 dengan probabilitas $=0,476>0,05$ artinya sand tidak memiliki pengaruh yang signifikan dan salinitas nilai t hitung sebesar $-0,138$ dengan probabilitas $=0,894>0,05$ artinya salinitas tidak memiliki pengaruh yang signifikan terhadap kerapatan mangrove.

Tabel 15. Kesimpulan Model Analisis Regresi Berganda Stasiun 2 Kerapatan Sedang

\begin{tabular}{lllll}
\hline Model & $\mathrm{R}$ & $\mathrm{R}^{2}$ & Adjusted $\mathrm{R}^{2}$ & Std. Error of the Estimate \\
\hline 1 & $0,388^{\mathrm{a}}$ & 0,151 & 0,334 & 219.58406
\end{tabular}

Berdasarkan Tabel 15 diperoleh nilai koefisien korelasi (R) sebesar 0,388 yang berarti hubungan clay, silt, sand dan salinitas dengan kerapatan mangrove dikategorikan berhubungan lemah. Nilai koefisien determinasi $\left(\mathrm{R}^{2}\right)$ sebesar 0,151 nilai ini menunjukkan sebesar 15,1\% kerapatan mangrove sedang dipengaruhi oleh clay, silt, sand dan salinitas, sisanya sebesar $98,5 \%$ dipengaruhi oleh faktor lain seperti faktor fisika kimia yang ada pada perairan.

Tabel 16. Persamaan Regresi Linear Ganda Stasiun 3 Kerapatan Rapat

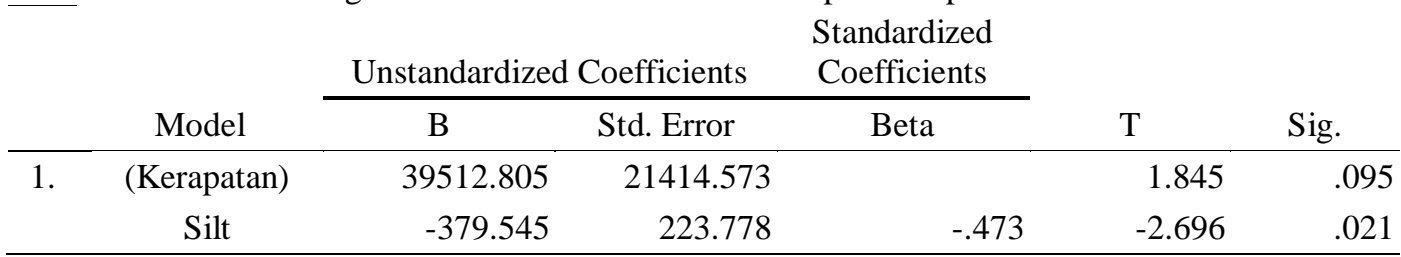

a. Dependent Variable: Kerapatan

Berdasarkan Tabel 16 model regresi linear berganda Stasiun 3 (Kerapatan Rapat) diperoleh persamaan yaitu $\mathrm{Y}=39512.805-379.545 \mathrm{X}_{2}$. Hasil analisis pada tabel menunjukkan silt nilai t hitung sebesar $-2,696$ dengan probabilitas $=0,021<0,05$ artinya silt memiliki pengaruh yang signifikan terhadap kerapatan mangrove.

Tabel 17. Kesimpulan Model Analisis Regresi Berganda Stasiun 3 Kerapatan Rapat

\begin{tabular}{lllll}
\hline Model & $\mathrm{R}$ & $\mathrm{R}^{2}$ & Adjusted $\mathrm{R}^{2}$ & Std. Error of the Estimate \\
\hline 1 & $0,473^{\mathrm{a}}$ & 0,223 & 0,271 & 1687.30034 \\
\hline
\end{tabular}

Berdasarkan Tabel 17 diperoleh nilai koefisien korelasi (R) sebesar 0,473 yang berarti hubungan silt dengan kerapatan mangrove dikategorikan berhubungan sedang. Nilai koefisien determinasi $\left(\mathrm{R}^{2}\right)$ sebesar 0,223 nilai ini menunjukkan sebesar 22,3\% kerapatan mangrove rapat dipengaruhi oleh silt, sisanya sebesar $97,8 \%$ dipengaruhi oleh faktor lain seperti faktor fisika kimia yang ada pada perairan.

\section{Hubungan Tekstur Sedimen dengan Kerapatan Mangrove}

Berdasarkan hasil analisa dengan menggunakan regresi linear berganda, tekstur sedimen berupa lumpur (silt) dan liat (clay) berhubungan kuat dengan kerapatan mangrove di stasiun 1 (kerapatan jarang), sedangkan di stasiun 2 (kerapatan sedang) tekstur sedimen dan salinitas memiliki hubungan lemah terhadap kerapatan mangrove dan untuk stasiun 3 (kerapatan rapat) lumpur (silt) dan salinitas memiliki hubungan sedang terhadap kerapatan mangrove. Hal tersebut dapat diartikan bahwa dari ke- 3 stasiun komposisi sedimen yang kaya akan lumpur akan menjadi tempat tumbuh yang baik untuk mangrove dengan jenis Rhizopora sp., sedangkan untuk substrat yang memiliki kandungan liat (clay) dan pasir (sand) biasanya menjadi tempat tumbuh yang baik untuk mangrove jenis Avicennia sp.. Kandungan lumpur (silt) mendominasi di semua stasiun pengamatan, hal tersebut dapat disebabkan karena letak lokasi kawasan mangrove yang dekat dengan pantai yang memiliki arus dan gelombang tinggi. Hal ini dipengaruhi oleh vegetasi mangrove pada lokasi penelitian yang padat sehingga dapat menyebabkan produksi serasah tinggi dan kemampuan akar mangrove dalam mengikat lumpur. Menurut Mahmud et al., (2014), jenis tanah yang mendominasi kawasan mangrove biasanya fraksi lumpur sebagai akibat rapat perakaran mangrove yang ada.

Berdasarkan dari hasil tekstur sedimen, substrat liat (clay) dan pasir (sand) tidak terlalu mendominasi, karena di lokasi penelitian didominasi oleh mangrove jenis Rhizopora sp.. Menurut Syah (2011), pada endapan lumpur yang lebih padat/kokoh akan sering ditumbuhi oleh Avicennia marina. Sedangkan lumpur yang lebih lunak menjadi tempat hidup yang ideal untuk Rhizopora mucronata, Rhizophora apiculata, dan Bruguiera serta Xylocarpus. Hal tersebut juga diperkuat oleh Arisandy et al., (2012), muara sungai yang didominasi oleh fraksi

\footnotetext{
${ }^{\circledR}$ Copyright by Management of Aquatic Resources (MAQUARES)
} 
liat dengan sedikit fraksi lumpur terlihat ditumbuhi oleh mangrove dengan jenis Avicennia marina. Daerah tersebut mempunyai tekstur tanah liat yang lebih banyak sehingga semakin besar pula sedimen dalam mengikat logam berat. Menurut Encik (2014), pasang surut dan arus yang membawa meterial sedimen dan subtrat yang terjadi secara periodik menyebabkan perbedaan dalam pembentukan zonasi mangrove, substrat berlumpur ini sangat baik untuk tegakan Rhizophora mucronata dan Avicennia marina. Substrat jenis lumpur berpasir memang merupakan substrat yang sangat cocok untuk tempat tumbuhnya jenis Rhizophora sp..

\section{KESIMPULAN} adalah:

Kesimpulan yang dapat diambil dari penelitian hubungan kerapatan mangrove terhadap laju sedimentasi

1. Struktur sedimen mangrove di Desa Pasar Banggi, Rembang didominasi oleh lumpur dengan nilai antara 90,74-100\%, sedangkan liat dan pasir sangat sedikit ditemukan di lokasi penelitian. Nilai liat berkisar antara 0-7,02\%, sedangkan pasir memiliki nilai berkisar antara 0-3,85\%.

2. Kerapatan mangrove di Desa Pasar Banggi didominasi oleh jenis mangrove Rhizophora sp.. Nilai kerapatan relatif Rhizophora sp. di stasiun 1, 2 dan 3 yaitu berkisar antara 837-25.400 pohon/ha. Kondisi tersebut tergolong baik.

3. Uji regresi linier berganda menunjukkan bahwa hubungan tekstur sedimen dengan kerapatan mangrove di stasiun 1 (kerapatan jarang) mempunyai hubungan yang sangat kuat dengan angka koefisien korelasi (R) sebesar 0,741, stasiun 2 (kerapatan sedang) mempunyai hubungan yang sangat lemah dengan angka koefisien korelasi $(\mathrm{R})$ sebesar 0,388, dan stasiun 3 (kerapatan rapat) mempunyai hubungan sedang dengan angka koefisien korelasi (R) sebesar 0,473.

\section{DAFTAR PUSTAKA}

Annas, N., Suryono, dan R. Pribadi. Kajian Konservasi Ekosistem Mangrove di Desa Pasar Banggi, Kabupaten Rembang. Journal of Maquares. 2(2) : 55-64.

Arisandy, K. R., E. Y. Herawati, dan E. Suprayitno. 2012. Akumuluasi Logam Berat Timbal (Pb) dan Gambaran Histologi pada Jaringan Avicennia marina (forsk.) Vierh di Perairan Pantai Jawa Timur. Jurnal Penelitian Perikanan 1(1) : 15-25

Auliyani, D., B. Hendrarto dan Kismartini. 2014. Partisipasi Masyarakat dalam Rehabilitasi Mangrove di Beberapa Desa Pesisir Kabupaten Rembang; Tinjauan Berdasarkan Tahap Perencanaan. Maspari journal., 6(1):13-19

Encik, N. F. 2014. Jenis dan Karakteristik Sedimen di Daerah Mangrove Perairan Teluk Antang Kecamatan Siantan Kabupaten Kepulauan Anambas. Skripsi. Universitas Maritim Raja Ali Haji. Tanjungpinang.

FAO. 2016. Soil Texture. ftp://ftp.fao.org/fi/cdrom/fao_training/FAO_Training/General/x6706e/x6706e06. htm(28 Februari 2016).

Jolliffe, I.T. Principal Component Analysis. Edisi kedua. Springer-Verlag. New York. 2002.

Karuniastuti, N. 2010. Peranan Hutan Mangrove Bagi Lingkungan Hidup. Forum Manajemen. 6(1): 1-10.

Kinasih, A. R. N., P. W. Purnomo, dan Ruswahyuni. 2015. Analisis Hubungan Tekstur Sedimen dengan Bahan Organik, Logam Berat (Pb dan $\mathrm{Cd}$ ) dan Makrozooenthos di Sungai Betahwalang, Demak. Diponegoro Journal of Maquares. 4(3). 99-107

Mahmud, Wardah, dan B. Toknok. 2014. Sifat Fisik Tanah di Bawah Tegakan Mangrove di Desa Tumpapa Kecamatan Balinggi Kabupaten Parigi Moutong. Jurnal Warta Rimba. 2(1) : 129 - 135.

Mitchell, K. 2007. Quantitative Analysis by The Point-Centered Quarter Method. Department of Mathematics and Computer Science Hobart and William Smith Colleges. Geneva. New York

Munandar, R. K., Muzahar, A. Pratomo. 2014. Karakteristik Sedimen di Perairan Desa Tanjung Momong Kecamatan Siantan, Kabupaten Kepulauan Anambas. Skripsi. Universitas Maritim Raja Ali Haji. Kepualuan Riau.

Susiana. 2011. Diversitas dan Kerapatan Mangrove, Gastropoda, dan Bivalvia di Estuari Perancak, Bali. Skripsi. Universitas Hasanudin. Makasar

Syah, C. 2011. Pertumbuhan Tanaman Bakau (Rhizopora mucronata) pada Lahan Restorasi Mangrove di Hutan Lindung Angke Kapuk Provinsi DKI Jakarta. Tesis. Institut Pertanian Bogor. Bogor. 